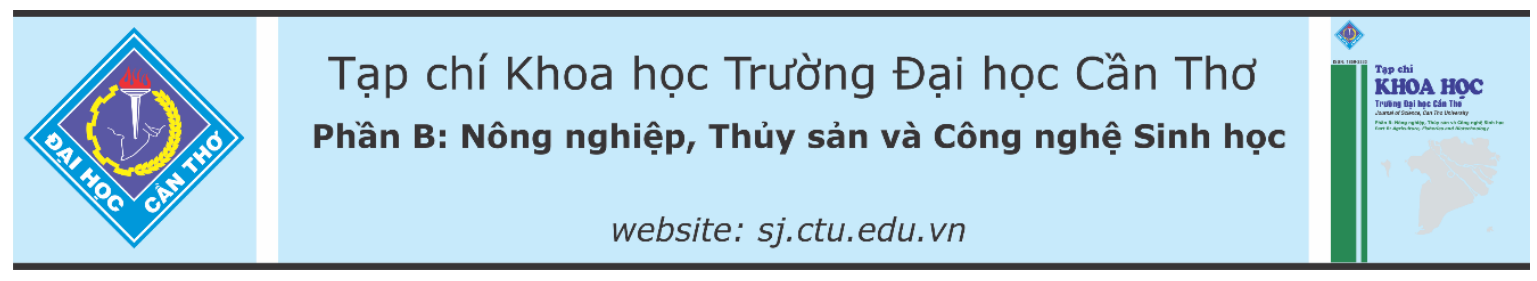

DOI:10.22144/ctu.jvn.2021.120

\title{
HIỆU QUẢ DẤU PHÂN TỦ GENE CHỬC NĂNG TRONG ĐÁNH GIÁ TÍNH TRẠNG CHẤT LƯợNG GIỐNG LÚA
}

Huỳnh Kỳ ${ }^{1 *}$, Nguyễn Văn Thép ${ }^{2}$, Văn Quốc Giang ${ }^{1}$, Nguyễn Văn Mạnh ${ }^{3}$, Trần In Đô ${ }^{2}$, Huỳnh Như Điền ${ }^{1}$, Lê Thị Hồng Thanh ${ }^{1}$, Chung Trương Quốc Khang ${ }^{2}$, Nguyễn Châu Thanh Tùng ${ }^{1}$, Nguyễn Lộc Hiền ${ }^{1}$ và Phạm Thị Bé Tư ${ }^{1}$

${ }^{1}$ Bộ môn Di truyền và Chọn giống cây trồng, Khoa Nông nghiệp, Truờng Đại học Cần Tho'

${ }^{2}$ Sinh viên ngành Công nghệ giống cây trồng, Khoa Nông nghiệp, Trường Đại học Cần Tho

${ }^{3}$ Học viên cao học ngành Di truyền và Chọn giống cây trồng, Khoa Nông nghiệp, Truờng Đại học Cần Tho

*Nguoòi chịu trách nhiệm về bài viết: Huỳnh Kỳ (email: hky@ctu.edu.vn)

\section{Thông tin chung:}

Ngày nhận bài: $10 / 02 / 2021$

Ngày nhân bài sủa: 15/04/2021

Ngày duyệt đăng: 20/08/2021

\section{Title:}

The effectiveness of functional markers for evaluation of rice quality traits

\section{Tù khóa:}

Amylose, BADH2, chi thi phân tủ gene chưc năng, $D R R-G L$, gene $W x$

\section{Keywords:}

Amylose, BADH2, DRR-GL, Functional marker, Gene Wx

\section{ABSTRACT}

Nowadays, the economy is better, consumers' demand for rice has also changed, they prefer rice with high quality such as soft and aroma cooked rice. To meet the demand of consumers about rice, the application of functional markers for selection high quality of rice was carried out to assess quality traits in imported rice varieties from rice GeneBank, Can Tho University for selection high quality rice varieties that cope with the above objectives. DRR-GL marker was used to identify the gene controlling GS3 grain length; while the Wx-in1 marker was used the Wx gene that controls the amylose trait, and the $B A D H 2$ gene control the aroma in rice. The results showed that 1 line (IR 86385-172-1-1-B) was with good quality such as elongated rice grain, $7.12 \mathrm{~mm}$ grain length, amylose content is low $17.51 \%$, very soft gelconsistency (level 1) $86.67 \mathrm{~mm}$, medium gelatinization temperature (level 5). This report was the prelimary step to select imported rice lines that may be used as starting materials for the quality breeding program in the future.

\section{TÓM TẮT}

Ngày nay khi nền kinh tế đang ngày càng phát triển, nhu cầu của người tiêu dùng về lúa gạo cũng thay đổi theo, người tiêu dùng hiện này có xu hướng thích sản phẩm gạo có hình thức đẹp và chất luợng cao nhu cơm nấu ra phải mềm dẻo và có mùi thom. Để đáp ứng nhu cầu thị hiếu của người tiêu dùng về chất lượng gạo, nghiên cứu được thực hiện nhằm chọn ra nhũng giống lúa có chất lương cao đáp úng muc tiêu trên. Dáu chỉ thị phân tư DRR-GL được sử dụng để xác định gene kiểm soát chiều dài hạt GS3; chỉ thị phân tử Wxin1 xác định gene Wx kiểm soát tính trạng amylose và gene chỉ thị phân tủ BADH2 xác định gene kiểm soát tính trạng mùi thơm. Qua kết quả nghiên cứu, các tính trạng chất lượng của 50 dòng lúa IRRI đã tuyển chọn được 1 dòng (IR 86385-172-1-1-B) có chất lương tốt nhu hạt gạo thon dài, chiều dài hạt 7,12mm, hàm luợng amylose thấp 17,51\%, độ bền thể gel rất mềm (cấp 1) 86,67mm, nhiệt trở hồ trung bình (cấp 5). Kết quả này đã chọn ra được dòng lúa nhập nội có thể làm vật liệu khởi đầu cho chuơng trình chọn giống chất lượng trong tương lai. 


\section{GIỚI THIẸU}

Cây lúa là một trong những cây trồng quan trọng ở Đồng bằng sông Cửu Long (ĐBSCL). Trồng lúa không chỉ là nguồn cung cấp lương thực chính, mà còn là sinh kế của người dân. Khu vực ĐBSCL chiếm hơn $50 \%$ sản lượng và hơn $90 \%$ lượng gạo xuất khẩu của cả nước. Tuy nhiên, gạo của Việt Nam còn gặp nhiều hạn chế về chất lượng, mặc dù nước ta có rất nhiều giống lúa khác nhau nhưng trong số đó chỉ mới có một vài giống đã khẳng định được vị trí trên thị trường thế giới còn lại hầu hết các giống chưa có thương hiệu và chưa được xuất hiện trên thị trường quốc tế. Trước thực trạng trên, để nâng cao thương hiệu gạo Việt Nam, Chính phủ đã ban hành Quyết định 706/QĐ-TTg ngày 21 tháng 5 năm 2015 nhằm xây dựng lại thương hiệu gạo Việt. Chính vì lý do trên công tác nghiên cứu và chọn giống ngày càng được chú trọng với mục tiêu tìm ra một số giống lúa có chất lượng thương phẩm cao đưa vào sản xuất để đáp ứng nhu cầu của người tiêu dùng trong và ngoài nước.

Chất lượng hạt gạo theo nghĩa hẹp thường đề cập đến chất lượng ăn uống hoặc cảm giác ngon miệng, trong khi chất lượng hạt gạo ở nghĩa rộng bao gồm nhiều khía cạnh. Nói chung, chất lượng hạt gạo bao gồm chất lượng xay chà, hình dạng hạt gạo, chất lượng gạo nấu và cảm quan, cũng như chất lượng dinh dưỡng và vệ sinh (Zhou et al., 2019). Theo nghiên cứu của Calingacion et al. (2014), các quốc gia các vùng khác nhau sẽ có tiêu chuẩn đánh giá gạo chất lượng khác nhau, ví dụ các quốc gia Đông Nám Á thích dạng hạt thon dài, trong khi các quốc gia ở Bắc Á thích dạng hạt tròn ngắn. Riêng Ấn Độ và Pakistan lại thích dạng hạt rất dài. Bên cạnh dạng hạt, hàm lượng amylose cũng là một trong những đặc tính dùng để đánh giá chất lượng hạt và thang đánh giá cũng khác nhau ở mỗi quốc gia. Ở Lào và một số tỉnh của Thái Lan, người dân thích gạo nếp (hàm lượng amylose thấp), trong khi người dân ở vùng Bắc Trung Quốc, Nhật Bản và Thái Lan lại thích gạo có hàm lượng amylose trung bình (Calingacion et al. 2014). Người dân ở vùng Nam Trung Quốc, Iran, Pakistan, Malaysia, Philippines, Việt Nam, Indonesia và Uruguay thích loại gạo có hàm lượng amylose trung bình. Riêng đối với Myanmar, Sri Lanka, Colombia, nhiều tỉnh của Ấn Độ, Ghana, Senegal, Suriname lại chuộng gạo có thành phần amylose cao (Calingacion et al. 2014). Qua đó cho thấy sở thích hay chất lượng gạo của mỗi quốc gia khác nhau nhưng nhìn chung nhu cầu đều là hình dạng hạt gạo phải đẹp, hàm lượng amylose thấp và có mùi thơm thì họ sẽ ưa chuộng giống đó.

Với sự phát triển nhanh chóng của việc nghiên cứu chức năng gene, hơn 2.000 gene đã được tìm thấy có chức năng kiểm soát các đặc tính nông học quan trọng và đã đánh giá được các cơ chế phân tử của chúng. Zhou et al. (2017) đã tìm thấy chiều dài hạt gạo được quyết định bởi gene $G S 3$ và nghiên cứu cũng cho thấy ở exon 2 của gene $G S 3$ từ $\mathrm{C}>\mathrm{T}$ đã quyết định nên chiều dài hạt gạo. Bên cạnh đặc tính chiều dài hạt, hàm lượng amylose là một trong những đặc tính quyết định đến chất lượng gao (Cai et al., 1998). Kết quả khảo sát cho thây có ít nhất 7 vị trí biến đổi ở gene GBSSI đã dẫn đến ảnh hưởng hàm lượng amylose trong hạt gạo (Zhang et al., 2019). Ngoài 2 đặc tính trên, mùi thơm của gạo cũng được xem là một trong những tiêu chí chọn giống chất lượng. Hợp chất 2-acetyl-1-pyrroline (2-AP) tích lũy trong hạt gạo sẽ cho ra mùi như bắp rang và mùi này được điều khiển bởi gene $O s B A D H 2$, khi gene này bị mất chức năng khi có đột biến xảy ở các vùng mã hóa sẽ giúp tổng hợp 2-AP (Bradbury et al., 2005). Dựa trên nhu cầu thực tế kết hợp với sự phát triển của khoa học, trong nghiên cứu này gene chức năng GS3, Waxy, OsBADH2 là ba gene liên quan đến đặc tính chất lượng được dùng để tìm ra các dòng lúa nhập nội chất lượng nhằm phục vụ cho công tác chọn tạo giống chất lượng trong tương lai.

\section{PHƯƠNG TIÊN PHƯƠNG PHÁP}

\subsection{Vật liệu thí nghiệm}

Nhằm tăng cường vât liệu di truyền 50 dòng lúa nhập nội có nguồn gốc từ Viện Nghiên cứu Lúa quốc tế (IRRI), hiện đang lưu trữ trong Ngân hàng Gene Trường Đại học Cần Thơ (Bảng 1). Đề tài được thực hiện tại Khoa Nông nghiệp, Trường Đại học Cần Tho. 
Bảng 1. Danh sách 50 dòng lúa IRRI dùng trong thí nghiệm

\begin{tabular}{clll}
\hline Stt & Tên dòng & Stt & Tên dòng \\
\hline 1 & IR29 & 26 & IR 77674-3B-8-2-2-8-3-4 \\
2 & IR 87989-8-1-B & 27 & IR 77674-3B-8-2-2-12-5-2 \\
3 & IR 85175-4-1-7-1-AJY1-B & 28 & IR 77660-B-9-1-3-2-1-17-4-1 \\
4 & IR 85252-6-3-1-1-AJY1-B & 29 & IR 85178-5-3-1-1 \\
5 & IR 83484-3-B-7-1-1-1 & 30 & IR 85197-5-1-2-1 \\
6 & IR 87869-2-AJY1-B & 31 & IR 83412-6-B-3-1-1-1 \\
7 & IR 86385-48-2-1-B & 32 & IR 83414-5-B-5-3-1-1 \\
8 & IR 86385-62-1-1-B & 33 & IR 83435-6-B-6-2-1-1 \\
9 & IR 86385-64-1-1-B & 34 & IR 83460-4-B-4-2-1-1 \\
10 & IR 86385-67-1-1-B & 35 & IR 83465-6-B-1-1-1-1 \\
11 & IR 86385-80-3-1-B & 36 & IR 83484-3-B-7-1-1-1 \\
12 & IR 86385-84-2-1-B & 37 & IR 83996-B-B-3-1 \\
13 & IR 86385-97-2-1-B & 38 & IR 78767-B-SDO1-3-AJY2 \\
14 & IR 86385-110-1-1-B & 39 & IR 83407-B-SDO4-3-AJY1 \\
15 & IR 86385-114-1-1-B & 40 & IR 84095-AJY1-2-SDO6-B \\
16 & IR 86385-122-1-1-B & 41 & IR 83422-B-AJY5-6-SDO2 \\
17 & IR 86385-170-1-1-B & 42 & IR 84086-11-B-AJY2-B \\
18 & IR 86385-172-1-1-B & 43 & IR 25997-B-B-B \\
19 & IR 83465-6-B-1-1-1-1 & 44 & IR 83412-6-B-3-1-1-1 \\
20 & IR 84649-308-7-1-B-AJY1-B & 45 & IR 83420-B-AJY3-7-SDO1 \\
21 & PSB Rc 88 & 46 & IR 84649-130-5-1-1-1 \\
22 & IR 72046-B-R-3 & 47 & IR 84089-7-3-AJY1-B \\
23 & IR 77674-3B-8-1-3-10-3-AJY2 & 48 & IR 85212-21-2-1-1 \\
24 & IR 77674-3B-8-2-2-13-4-AJY2 & 49 & IR 85212-186-1-1-1 \\
25 & IR 77674-3B-8-2-2-6-3-5 & 50 & IR 85212-73-1-1-1 \\
\hline
\end{tabular}

\subsection{Phương pháp phân tích}

2.2.1. Đặc tính chiều dài và hình dạng hạt gạo

Kích thước (dài, rộng) và tỷ lệ dài/rộng của 10 hạt gạo lức (bóc vỏ trấu) được đo và tính giá trị trung bình. Phân loại hạt gạo theo thang điểm của IRRI (2013) (Bảng 2).

Bảng 2. Phân loại kích thước, hình dạng hạt gạo lức theo tiêu chuẩn IRRI (2013)

\begin{tabular}{clrlr}
\hline Cấp độ & Nhóm hạt & Chiều dài hạt gạo $(\mathbf{m m})$ & Dạng hạt & Tỷ lệ Dài/Rộng \\
\hline 1 & Rất dài & $>7,50$ & Thon dài & $>3,0$ \\
3 & Dài & $6,61-7,50$ & Trung bình & $2,1-3,0$ \\
5 & Trung bình & $5,50-6,60$ & Bầu & $1,1-2,0$ \\
9 & Ngắn & $<5,50$ & Tròn & $<1,1$ \\
\hline
\end{tabular}

\subsubsection{Phương pháp phân tích hàm luợng amylose}

Định lượng amylose theo phương pháp Juliano (1971) có cải tiến theo Khoomtong and Noohorm (2015). Đầu tiên hạt gạo được bóc vỏ trấu, tiếp theo nghiền thật mịn và sau đó đo độ ẩm rồi về quy về độ ẩm chuẩn $12 \%$, tiến hành cân mẫu.

Cân $25 \mathrm{mg}$ bột đã nghiền mịn (ẩm độ $12 \%$ ), cho vào ống nghiệm $15 \mathrm{~mL}(100 \times 13 \mathrm{~mm})$. Thêm 0,25 $\mathrm{mL}$ ethanol $95 \%$, lắc đều. Thêm $2,25 \mathrm{~mL} \mathrm{NaOH} 1 \mathrm{M}$ rồi trộn đều hỗn hợp. Đun hỗn hợp dung dịch trong nước sôi 10 phút, sau đó để nguội ở nhiệt độ phòng.
Cho tất cả dung dịch trong ống nghiệm vào bình định mức $25 \mathrm{~mL}$. Chuẩn đến vạch định mức, để qua đêm. Rút $1,25 \mathrm{~mL}$ dung dịch tinh bột sang bình định mức $25 \mathrm{~mL}$. Thêm $0,25 \mathrm{ml}$ acid acetic $1 \mathrm{M}$ và $0,5 \mathrm{ml}$ $\mathrm{dd}$ Iod, lắc đều. Chuẩn nước cất lên vạch định mức, lắc đều, giữ ở nhiệt độ phòng trong 20 phút.

Đo mẫu: độ hấp thụ được đo trên máy đo quang phổ ở bước sóng $620 \mathrm{~nm}$. Giá trị độ hấp thụ được chuyển đổi thành hàm lượng amylose dựa trên đường cong chuẩn đã được thiết lập. Mẫu blank được chuẩn bị và kiểm tra tương tự như các mẫu (không có tinh bột). Cuối cùng ghi nhận và phân tích 
kết quả. Đánh giá hàm lượng amyose theo thang đánh giá của Juliano and Villareal (1993) (Bảng 3).

Bảng 3. Thang đánh giá hàm lượng amylose của Juliano and Villareal (1993)

\begin{tabular}{lr}
\hline Phân loại & Tỷ lệ (\%) amylose \\
\hline Nếp & $0-5 \%$ \\
Rất thấp & $5,1-12 \%$ \\
Thấp & $12,1-20 \%$ \\
Trung bình & $20,1-25 \%$ \\
Cao & $>25 \%$ \\
\hline
\end{tabular}

\subsubsection{Phương pháp phân tích nhiệt trở hồ}

Thực hiện theo phương pháp của Little et al. (1958), và dựa trên thang điểm của IRRI (2013) (Bảng 4). Cấp trung bình được tính theo công thức sau:

Cấp trở hồ $=\frac{\sum x_{i} \times n}{N}$

Trong đó:

$x_{i}$ là cấp trở hồ

$n$ là số hạt có cấp nhiệt trở hồ $x_{i}$

$\mathrm{N}$ là số hạt thử nghiệm

Bảng 4. Thang điểm đánh giá chỉ tiêu nhiệt trở hồ (IRRI, 2013)

\begin{tabular}{clll}
\hline Cấp & Độ lan rộng & Độ phân hủy kiềm & Nhiệt trở hồ \\
\hline 1 & Hạt không bị ảnh hưởng & Thấp & Cao \\
2 & Hạt phồng lên & Thấp & Cao \\
3 & Hạt phồng lên rìa hẹp không rõ & Thấp/Trung bình & Cao/Trung bình \\
4 & Hạt phồng lên rìa rộng và rõ & Trung bình & Trung bình \\
5 & Hạt bị tách rời, rìa rộng và rõ & Trung bình & Trung bình \\
6 & Hạt tan và kết với rìa & Cao & Thấp \\
7 & Hạt tan hoàn toàn và hòa lẫn vào nhau & Cao & Thấp \\
\hline
\end{tabular}

2.2.4. Phuoong pháp phân tích độ bền thể gel (Cagampang et al., 1973)

Các mẫu gạo được tách vỏ trấu, sau đó nghiền mịn và đo ẩm độ hạ gạo. Cân mẫu (100 mg với ẩm độ $12 \%)$ cho vào ống nghiệm $(100 \times 13 \mathrm{~mm})$, tiếp đến thêm $0,2 \mathrm{~mL}$ ethanol $95 \%$ có chứa $0,025 \%$

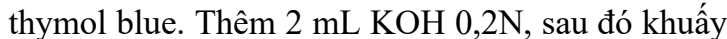
đều bằng máy Vortex. Đậy ống nghiệm và đem đun cách thủy (nhiệt độ $100^{\circ} \mathrm{C}$ trong 8 phút, lấy ra để yên 5 phút, sau đó làm lạnh bằng nước đá trong 20 phút. Cuối cùng đọc và ghi nhận kết quả bằng cách để ống nghiệm nằm ngang trên bề mặt phẳng của giấy kẻ ô ly và sau 60 phút thì tiến hành đo chiều dài thể gel (từ đáy đến mí trên của thể gel), đơn vị mm. Đánh giá độ bền thể gel theo thang điểm của IRRI (2013) (Bảng 5).

Bảng 5. Thang điểm đánh giá độ bền thể gel của IRRI (2013)

\begin{tabular}{llc}
\hline Chiều dài thể gel $(\mathbf{m m})$ & $\begin{array}{l}\text { Loại độ bền } \\
\text { thể gel }\end{array}$ & Cấp \\
\hline $81-100$ & Rất mềm & 1 \\
$61-80$ & Mềm & 3 \\
$41-60$ & Trung bình & 5 \\
$35-40$ & Cứng & 7 \\
$<35$ & Rất cứng & 9 \\
\hline
\end{tabular}

2.2.5. Phuoong pháp phân tích cảm quan mùi thom

Mùi thơm của gạo được đánh giá theo phương pháp cảm quan, qui trình được thực hiện theo các bước sau. Trước tiên lấy khoảng 10 hạt gạo của mỗi giống đã được bóc vỏ trấu, làm trắng và nghiền. Sau đó bột gạo nghiền được đặt trong ống nghiệm 100 $\mathrm{ml}$ chứa $500 \mu \mathrm{KOH} 1,7 \%$, tiếp đến đậy nắp lại và để 10 phút ở nhiệt độ phòng. Cuối cùng đánh giá mùi thơm bằng phương pháp cảm quan với 10 người và được đánh giá theo IRRI (2013) (Bảng 6). Sử dụng gạo của giống lúa Jasmine làm đối chứng (cấp 2) rất thơm, gạo Đài Thơm 8 làm đối chứng (cấp 1) thơm nhẹ và IR50404 làm đối chứng (cấp 0) không thơm.

Bảng 6. Đánh giá mùi thơm cảm quan (IRRI, 2013)

\begin{tabular}{cl}
\hline Cấp & Mùi thơm \\
\hline 0 & Không thơm \\
1 & Thơm nhẹ \\
2 & Rất thơm \\
\hline 2.2.6. $\begin{array}{l}\text { Phuoong pháp phân tích kiểu gene liên } \\
\text { quan đến chất luợng }\end{array}$
\end{tabular}

Mẫu lá non của 50 dòng lúa thí nghiệm được ly trích theo quy trình của Doyle and Doyle (1990). DNA thu được tiếp tục đánh giá kiểu gene dựa vào các mồi đã được tổng hợp có trình tự được liệt kê trong Bảng 7 bằng phương pháp PCR. 
Bảng 7. Trình tự các đoạn mồi dùng cho nhận diện kiểu gene quy định tính trạng chất lượng

\begin{tabular}{|c|c|c|c|}
\hline $\begin{array}{l}\text { Tên } \\
\text { mồi }\end{array}$ & Trình tự mồi (5’ đến 3') & Sự bắt cặp các mồi & $\begin{array}{c}\text { Kích thước } \\
\text { bp }\end{array}$ \\
\hline \multicolumn{4}{|c|}{ Kiểu gene $\boldsymbol{W} \boldsymbol{x}$ (Cai et al., 2015) } \\
\hline GF & TACAAATAGCCACCACA & \multirow{2}{*}{ GF-TR (band chung) } & \\
\hline TR & GATCAGCCTAACCAAACA & & 387 \\
\hline GR & $\begin{array}{l}\text { GGGAAACAAAGAATTATAAACATATAT } \\
\text { GTACAC }\end{array}$ & GF-GR (band G) & 207 \\
\hline $\mathrm{TF}$ & CATCAGGAAGAACATCTGCAAGT & TF-TR (band T) & 235 \\
\hline \multicolumn{4}{|c|}{ Kiểu gene $\boldsymbol{B A D H 2}$ (Bradbury et al., 2005) } \\
\hline $\begin{array}{l}\text { ESP } \\
\text { EAP }\end{array}$ & $\begin{array}{l}\text { TTGTTTGGAGCTTGCTGATG } \\
\text { AGTGCTTTACAAAGTCCCGC }\end{array}$ & ESP-EAP (band chung) & 577 \\
\hline INSP & CTGGTAAAAAGATTATGGCTTCA & \multirow{2}{*}{$\begin{array}{l}\text { INSP-EAP (band không } \\
\text { thơm) } \\
\text { IFAP-ESP (band thơm) }\end{array}$} & 355 \\
\hline IFAP & CATAGGAGCAGCTGAAATATATACC & & 257 \\
\hline \multicolumn{4}{|c|}{ Kiểu gene $\boldsymbol{G S 3}$ (Ramkumar et al., 2010) } \\
\hline EFP & AGGCTAAACACATGCCCATCTC & EFP-ERP (band chung) & 365 \\
\hline IRSP & AACAGCAGGCTGGCTTACTCTCTG & ERP-IFLP (band hat dài) & 262 \\
\hline IFLP & ACGCTGCCTCCAGATGCTGA & EFP-IRSP (band hạt ngắn) & 147 \\
\hline
\end{tabular}

Sản phẩm PCR được điện di với gel agarose 2\% $(w / v)$ đối với sản phẩm $\mathrm{PCR}$ gene Waxy và $\mathrm{BADH} 2$, riêng sản phẩm PCR gene GS3 thì được điện di bằng gel polyacrylamide $8 \%$, thang chuẩn $1 \mathrm{~kb}$ plus được sử dụng để ước lượng kích thước band.

\subsubsection{Phương pháp phân tích số liệu}

Tất cả các số liệu được xử lý trên Microsoft Excel 2010. Số liệu được phần tích phần mềm statgraphics 18 (Statgraphics, 1988) để phân tích thống kê mô tả (số trung bình, độ lệch chuẩn), so sánh các trung bình nghiệm thức bằng phương sai (oneway ANOVA) và kết hợp so sánh các cặp trung bình nghiệm thức bằng kiểm định Tukey HSD, giá trị $\mathrm{F}$ và hệ số biến động $\mathrm{CV}(\%)$ được tính thông qua bảng phân tích phương sai và thống kê mô tả, và sử dụng phần mềm Origin phiên bản 2017 để vẽ biểu đồ.

\section{KẾT QUẢ THẢO LUẬN}

\section{1. Đặc tính chiều dài và hình dạng hạt gạo}

Kích thước hạt là yếu tố quyết định chính đến năng suất cây trồng (Harlan et al., 1972), cụ thể được biểu thị bằng chiều dài, chiều rộng và tỷ lệ dài/rộng của hạt, là yếu tố quyết định chính đến chất lượng bề ngoài hạt. Đây là một đặc điểm nông học quan trọng đối với chọn lọc nhân tạo trong chọn giống lúa (McKenzie \& Rutger, 1983).

\subsubsection{Chiều dài hạt gạo}

Chiều dài hạt gạo là một trong những thông số để phân loại gạo xuất khẩu và còn phụ thuộc rất lớn vào thị hiếu người tiêu dùng của từng quốc gia trên thế giới (Jenning et al., 1979). Hình 1B cho thấy chiều dài hạt gạo có sự khác biệt thống kê ớ mức ý nghĩa $1 \%$. Trong 50 dòng nghiên cứu, có 15 dòng thuộc cấp 1 (hạt rất dài) với số thứ tự dòng $(16,23$, $24,25,26,27,30,31,32,35,37,39,41,42,48$ ) biến thiên từ 7,56-9,38 mm, có 25 dòng thuộc cấp 3 (hạt dài) với số thứ tự dòng $(1,2,3,6,7,8,9,10,11,12$, $13,14,17,18,28,29,33,38,40,43,44,45,46,47$, 49) biến thiên từ $6,63-7,44 \mathrm{~mm}$, các dòng còn lại thuộc cấp 5 (hạt trung bình) biến thiên từ 5,76-6,6 $\mathrm{mm}$. Qua khảo sát đã tuyển chọn được 31 dòng lúa có chiều dài hạt $\geq 7 \mathrm{~mm}$ (dao động trong khoảng 7,00-9,38 mm), những dòng này có khả năng đáp ứng nhu cầu thị hiếu của người tiêu dùng trên thế giới (Bùi Chí Bửu \& Nguyễn Thị Lang, 2000). Tuy nhiên theo phân loại của IRRI (2013) thì giống chiều dài hạt gạo $\geq 6,5 \mathrm{~mm}$ là giống có kiểu hình hạt dài.

Theo Ramkumar et al. (2010), gene GS3 thuộc nhiễm sắc thể số 3 là gene quan trọng nhất chịu ảnh hưởng từ $80-90 \%$ so với các gene kiểm soát chiều dài hạt gạo khác. Một đột biến ở exon thứ 2 của gene này đã làm thay đổi chiều dài hạt gạo. Dựa trên đặc điểm này, Ramkumar et al. (2010) đã sử dụng hệ thống mồi DRR-GL trong nghiên cứu nhằm xác định gene $G S 3$ kiểm soát chiều dài hạt. Hai đoạn mồi EFP/ERP khuếch đại một vùng 365 bp gồm cả alen trội và lặn. Các cặp mồi đặc hiệu cho từng alen 
EFP/IRSP khuếch đại vùng 147 bp cho các giống/dòng có chiều dài hạt ngắn dưới $6,4 \mathrm{~mm}$ và cặp mồi ERP/IFLP khuếch đại vùng 262 bp nhận diện cho giống có chiều dài hạt gạo dài lớn hơn 6,4 $\mathrm{mm}$. Qua kết quả phổ điện di sản phẩm PCR bằng mồi DRR-GL (Hình 2), 50 dòng lúa IRRI có 8 dòng kích thước band là 147 bp chiều dài hạt gạo là ngắn (dưới $6,4 \mathrm{~mm}$ ) và 42 dòng có kích thước band là 262 bp chiều dài hạt gạo là dài (lớn hơn $6,4 \mathrm{~mm}$ ). So sánh giữa hai phương pháp truyền thống và ứng dụng dấu chỉ thị phân tử cho thấy dấu chỉ thị phân tử giải thích đúng 74,2\% sự biểu hiện kiểu hình.

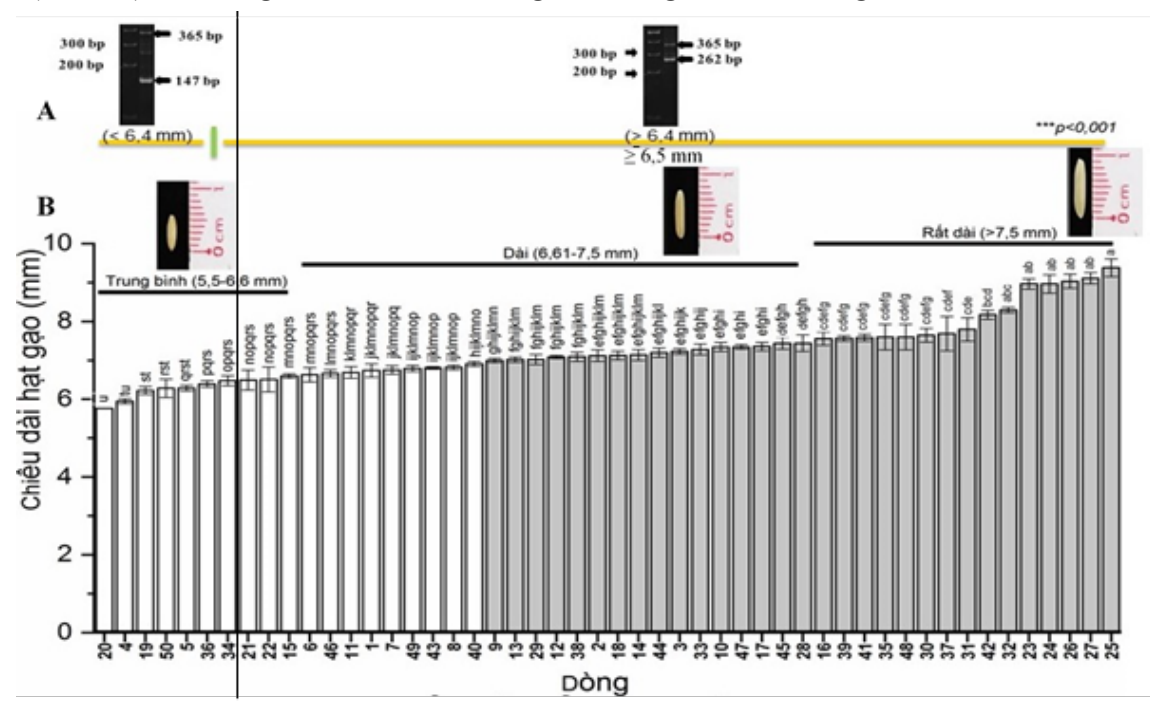

Hình 1. Chiều dài hạt gạo

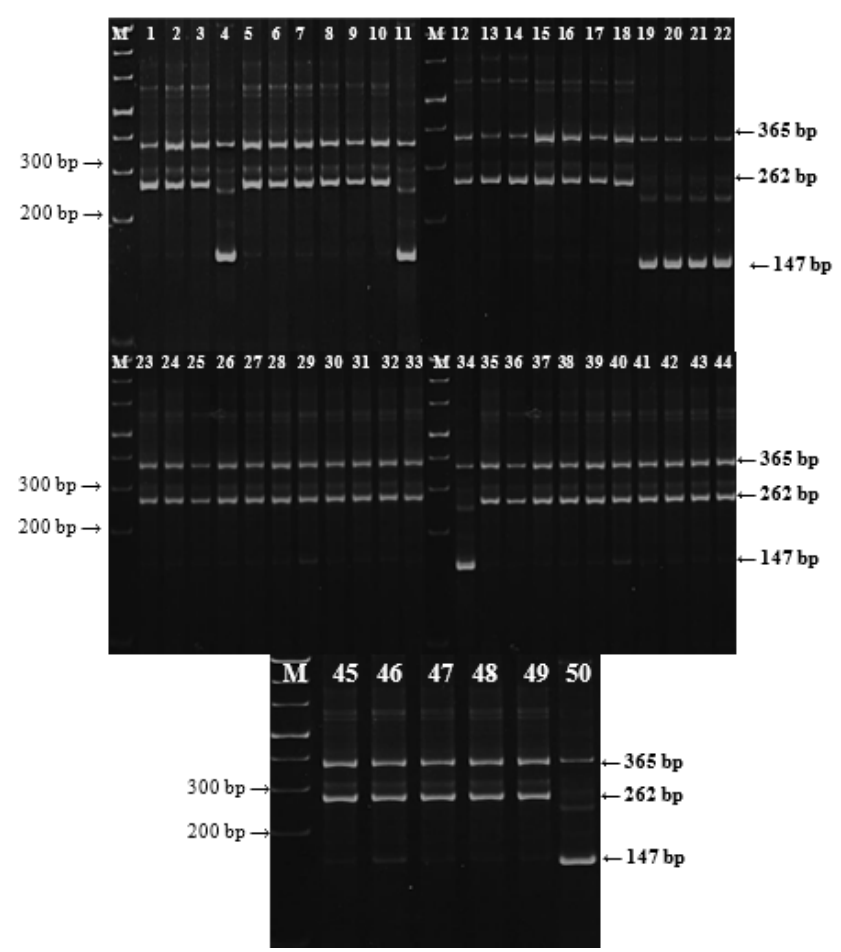

Hình 2. Phổ điện di sản phẩm PCR với mồi GS3 trên gel polyacrylamide 8\%

(M: thang chuẩn 1kb plus, 1-50: tuoong úng số thứ tư các dòng lúa IRRI được trình bày trong Bảng 1)

A. Dấu phân tử DRR-GL nhận diện chiều dài hạt gạo; B. Biểu đồ chiều dài hạt gạo đo đuợc, thanh màu xám biểu thi chiều dài hạt gạo $\geq 7,0 \mathrm{~mm}$, thanh màu đen biệu thi giống có chiều dài hạt gạo $\geq 6,5 \mathrm{~mm}$. 


\subsubsection{Hình dang hat gạo}

Tỷ lệ dài/rộng của các dòng lúa được thể hiện qua Hình 3 cho thấy không có sự khác biệt ý nghĩa thống kê. Hầu hết các dòng đều thuộc cấp 1 (hạt thon dài) và dao động trong khoảng 3,61-5,4. Dòng có tỷ lệ dài/rộng cao nhất là dòng số thứ tự $25(5,4)$ và dòng thấp nhất là dòng số thứ tự $20(3,61)$. Theo Nguyễn Thị Lang và Bùi Chí Bửu (2004), tỷ lệ dài/rộng hạt là một trong những tính trạng quan trọng nhằm đánh giá đa dạng di truyền của các loài cây có hạt.

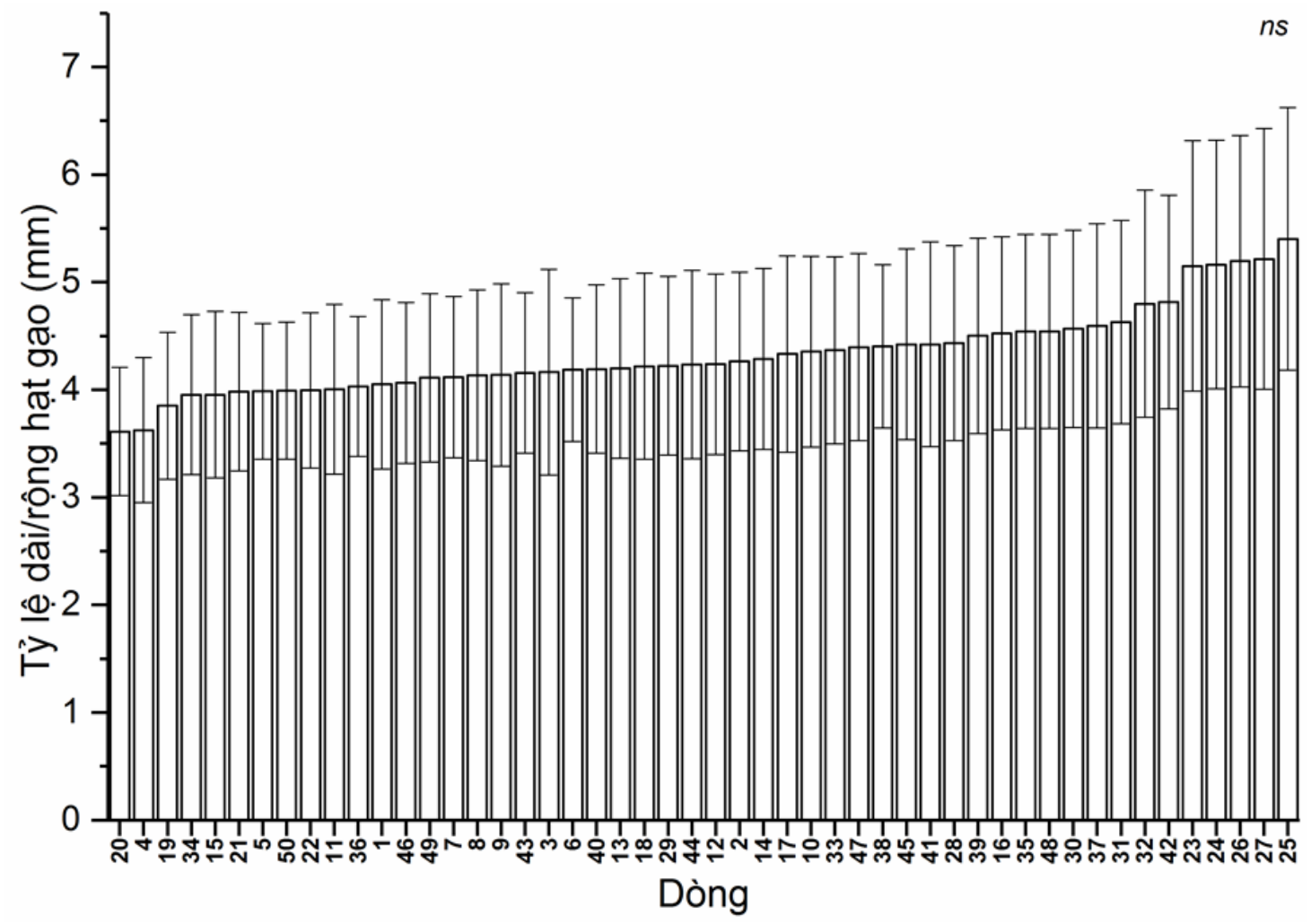

Hình 3. Tỷ lệ dài/rộng của hạt gạo

\subsection{Hàm lượng amylose}

Hình $4 \mathrm{~B}$ cho thấy hàm lượng amylose của 50 dòng lúa có sự khác biệt thống kê ở mức ý nghĩa 1\%, biến thiên từ $14,43-30,35 \%$. Có 13 dòng có số thứ tự là $(1,2,10,15,16,18,19,24,40,42,44,45,47)$ có hàm lượng amylose ở mức thấp (dao động từ $14,33-19,55 \%)$ và 21 dòng có số thứ tự là $(3,4,5,6$, $9,11,12,13,14,17,20,21,23,25,26,27,29,31$, $36,39,43)$ có hàm lượng amylose ở mức trung bình (dao động từ 20,23-24,48\%). Còn lại 16 dòng trong tổng 50 dòng lúa IRRI có hàm lượng amylose ở mức cao (dao động từ 25,42-30,35\%).

Kết quả đã phân tích cho thấy 34 dòng lúa có số thứ tự là $(3,4,5,6,9,11,12,13,14,17,20,21,23$, $25,26,27,29,31,36,39,43$ ) có hàm lượng amylose ở mức thấp-trung bình trong số 50 dòng lúa. Gạo có hàm lượng amylose ở mức cao sẽ có độ trương nở lớn và độ phân rã cao khi được nấu. Ngược lại, gạo có hàm lượng amylose ở mức thấp, khi nấu dễ bị nhão và cơm sẽ dính hơn. Ở các quốc gia trồng lúa trên thế giới, người tiêu dùng thường hay chọn các giống lúa có hàm lượng amylose ở mức trung bình (Nguyễn Ngọc Đệ, 2008). Một trong những chỉ tiêu quan trọng để đánh giá chất lượng của gạo là hàm lượng amylose. Gene $W x$ điều khiển hàm lượng amylose trong lúa gây đột biến thay thế $\mathrm{G} \rightarrow \mathrm{T}$ ở +1 loci tại vị trí cắt giữa exon và intron thứ nhất, dựa vào kết quả đó làm cho hàm lượng amylose bị giảm. Cai et al. (2015) đã thiết kế 4 mồi GF, TR và $G R$, TF. Bốn mồi tạo ra ba cặp sản phẩm khuếch đại, GFTR khuếch đại một đoạn DNA có độ dài 387 bp nhận diện vùng gene quy định hàm lượng amylose, GF-GR khuếch đại một đoạn DNA có độ dài 207 bp (G) nhận diện vùng gene thể hiện hàm lượng amyse cao và TF-TR khuếch đại một đoạn DNA có độ dài 235 bp (T) nhận diện vùng gene thể hiện hàm lượng amylose thấp. 
Qua kết quả phổ diện di sản phẩm PCR trong thí nghiệm của 50 dòng lúa IRRI (Hình 5), có 15 dòng có kích thước band ở vị trí 235 bp là dòng có số thứ tự $(6,9,13,14,18,19,20,21,22,23,24,25,26,27$, 28) thể hiện hàm lượng amylose thấp. Còn lại 35 dòng có kích thước band ở vị trí 207 bp thể hiện hàm lượng amylose cao. Từ kết quả phân tích kiểu gene nhờ dấu chỉ thị phân (Hình 3), phân tích kiểu gene Waxy bằng 4 mồi trên cho kết quả chính xác trên $82 \%$ về hàm lượng amylose, điều này góp phần vào trong công tác chọn giống lúa chất lượng nhanh hơn và giảm chi phí. Kết quả đã chọn được 15 giống có hàm lượng amylose thấp dưới $20 \%$ mang kiểu gene $\mathrm{T}$ phù hợp với nhu cầu chọn giống hiện nay.

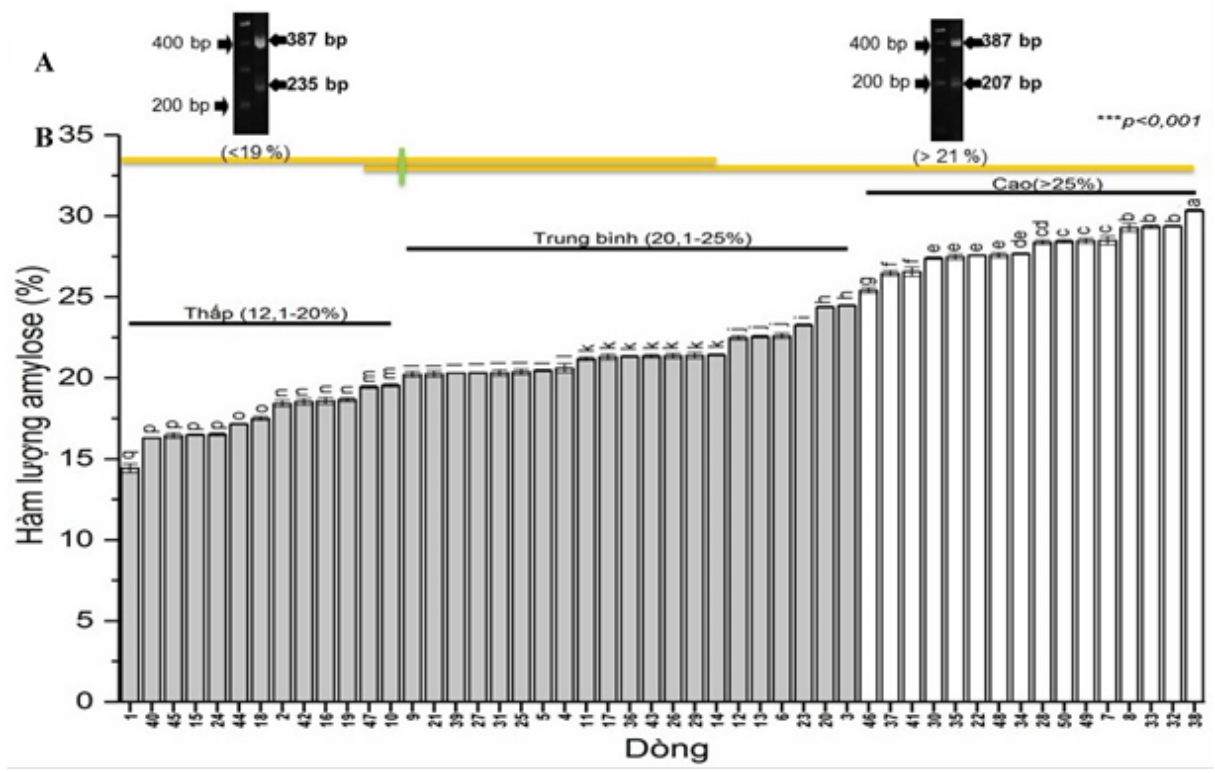

Hình 4. Hàm lượng amylose của 50 dòng lúa IRRI

(A: Chỉ thị phân tử Wx nhận diện hàm luợng amylose trong gạo; B: Thanh màu xám có hàm luợng amylose < 25\%)

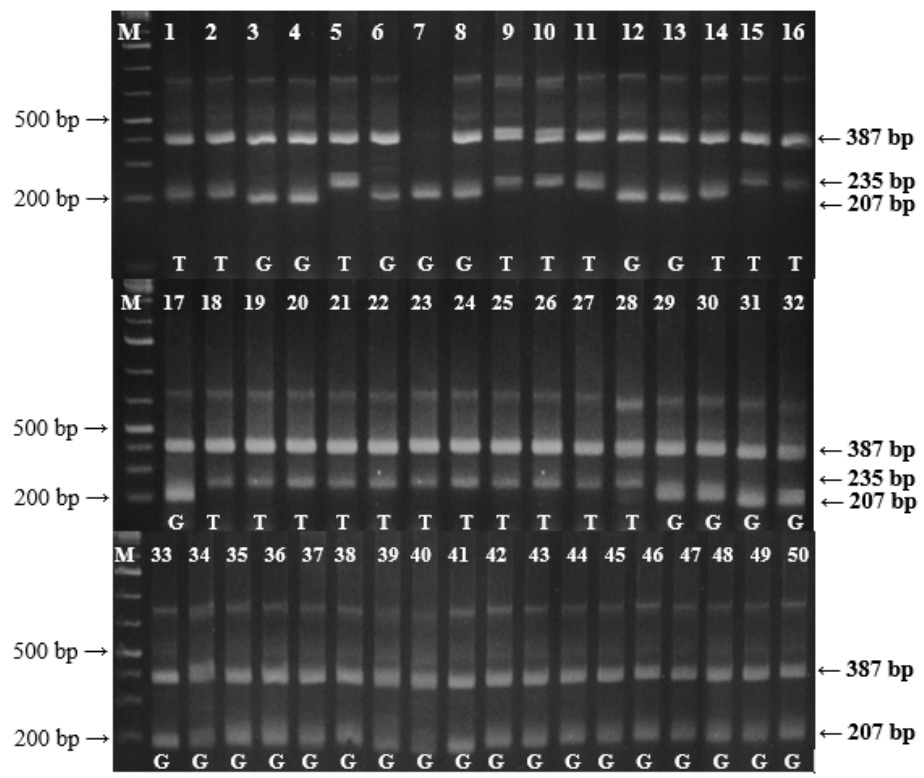

Hình 5. Phổ điện di sản phẩm PCR với mồi Waxy trên gel agarose $2 \%$ nhận diện các giống có mang gene đột biến $\boldsymbol{G} \rightarrow \boldsymbol{T}$

(M: thang chuẩn lkb plus, 1-50: tương úng số thư tụ các dòng lúa IRRI được trình bày trong Bảng 1) 


\subsection{Nhiệt trở hồ}

Kết quả đánh giá nhiệt trở hồ (Hình 6) cho thấy có 11 dòng lúa trong tổng 50 dòng có nhiệt trở hồ thấp (cấp 6$)$ đó là dòng có số thứ tự $(7,13,14,17$, $23,24,25,26,27,36,38)$ và 2 dòng có nhiệt trở hồ thấp (cấp 7) là dòng 32 và 35 . Những dòng có nhiệt trở hồ trung bình cấp 5 chỉ có 3 dòng số thứ tự (5, 18 và 43 ). Trong đó 25 dòng có nhiệt trở hồ cao cấp 2 số thứ tự đó là $(1,2,3,4,6,9,10,12,15,16,20$, $21,29,30,31,33,34,39,40,42,44,46,47,49,50)$.
Các dòng có số thứ tự còn lại có nhiệt trở hồ cao (cấp 3).

Theo Bùi Chí Bửu và Nguyễn Thị Lang (2000), nhiệt trở hồ có liên quan đến thời gian nấu cơm, gạo có nhiệt trở hồ cao thì dẫn đến cần nhiều nước và nhiều thời gian để nấu hơn là gạo có nhiệt trở hồ thấp hay trung bình. Các dòng lúa có nhiệt trở hồ trung bình (cấp 5) là các dòng tối ưu cho việc chọn phẩm chất gạo. Vì thế, 3 dòng lúa có số thứ tự $(5,18$ và 43) là 3 dòng có phẩm chất tốt để phục vụ cho việc chọn tạo giống lúa.
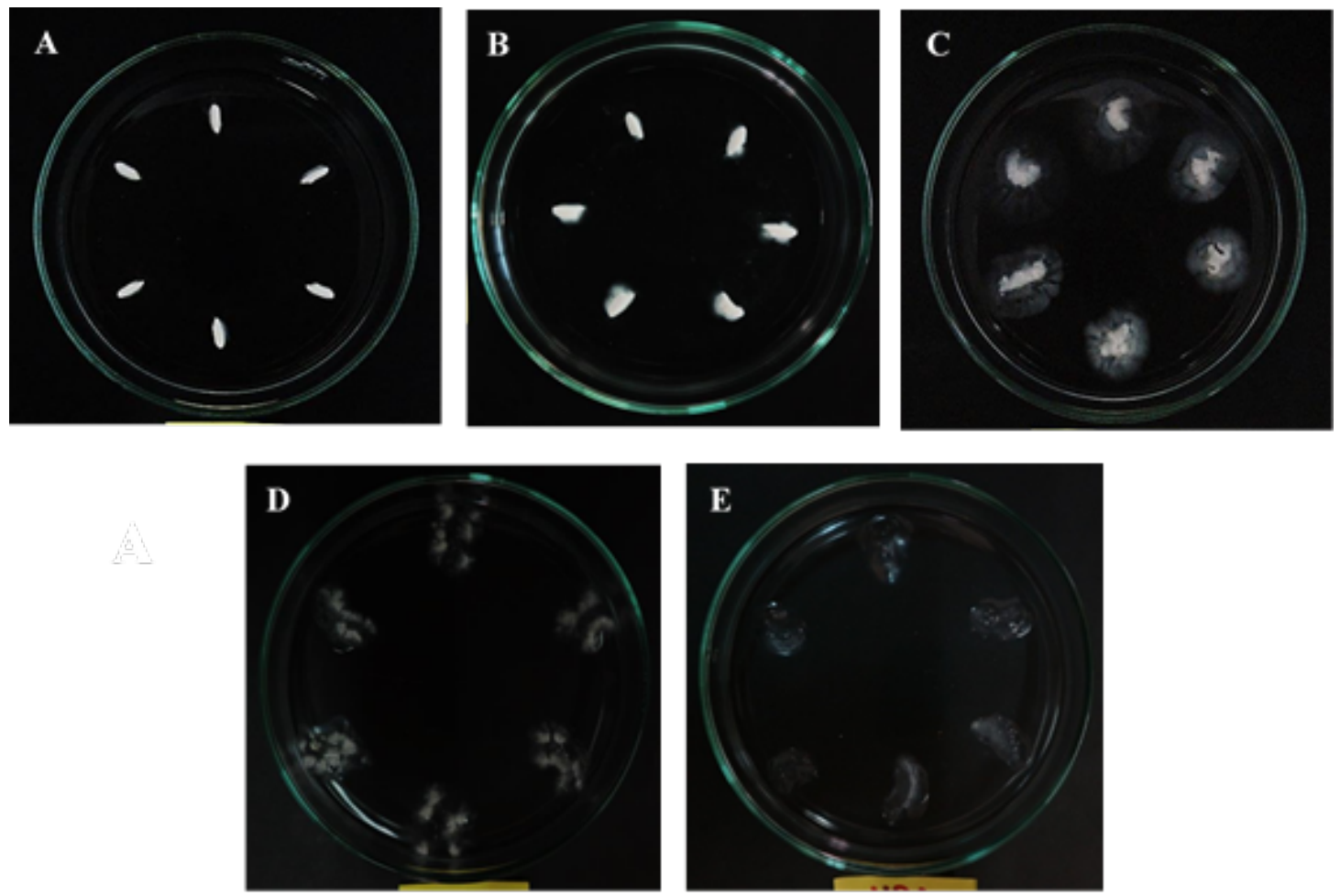

Hình 6. Cấp độ của nhiệt trở hồ các mẫu thí nghiệm: $\mathrm{A}$, cấp 2; B, cấp 3; C, cấp 5; D, cấp 6; E, cấp 7

\section{4. Độ bền thể gel}

Kết quả phân tích độ bền thể gel trên 50 dòng lúa IRRI được thực hiện theo phương pháp của Graham (2002) dựa trên sự khác biệt về tính liên kết tinh bột (Cruz \& Khush, 2000) và được đánh giá dựa trên thang điểm của IRRI (2013). Qua Hình 7, trong 50 dòng lúa IRRI có sự khác biệt thống kê ở mức ý nghĩa $1 \%$, các dòng dao động trong khoảng từ $(22,67-100 \mathrm{~mm})$. Có 13 dòng chiều dài thể gel thuộc cấp 1 (rất mềm) biến thiên từ $(83,67-100 \mathrm{~mm})$ đó là số thứ tự $(1,3,4,5,6,7,8,12,18,31,33,34,50)$. 15 dòng có chiều dài thể gel đạt cấp 3 (mềm) biến thiên $(61-80,33 \mathrm{~mm})$ là số thứ tự $(2,9,10,11,15$, $16,17,19,21,29,30,36,38,39,49)$. Và 19 dòng có chiều dài thể gel đạt cấp 5 (trung bình) đó là số thứ tự $(13,14,22,23,24,25,26,27,28,32,35,37$, $40,42,43,44,45,46,47)$. Cuối cùng là 3 dòng có chiều dài thể gel đạt cấp 9 (rất cứng) biến thiên từ $(22,67-27,67 \mathrm{~mm})$. Độ bền thể gel còn là một trong những chỉ tiêu quan trọng liên quan đến phẩm chất gạo, quyết định đến độ mềm dẻo của cơm để nguội sau khi nấu (Nguyễn Thị Lang, 2005). Giữa các giống trong cùng một nhóm hàm lượng amylose của giống có độ bền thể gel mềm hơn sẽ được ưa chuộng hơn và gạo khi được nấu chín sẽ mềm hơn (Khush et al., 1979; Nguyễn Ngọc Đệ, 2008). Vì vậy, ở chỉ tiêu này đã loại trừ 22 dòng có độ bền thể gel thuộc nhóm trung bình và rất cứng vì không được thị trường ưa chuộng, các dòng còn lại đều thuộc nhóm gel từ mềm-rất mềm phù hợp với nhu cầu của người tiêu dùng. 


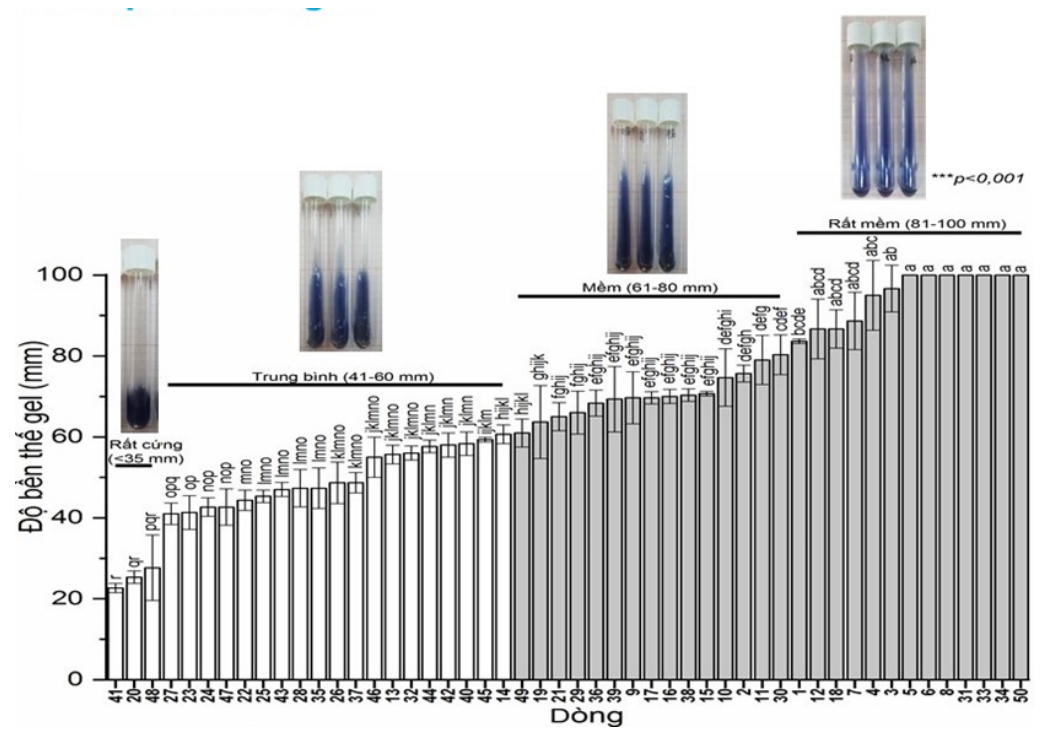

Hình 7. Độ bền thể gel của 50 dòng lúa thí nghiệm, thanh màu xám tương ứng thể hiện gạo mềm có chiều dài thể gel $>60 \mathrm{~mm}$

\subsection{Phân tích mùi thơm}

Mùi thơm các dòng lúa được phân tích theo phương pháp phân tích cảm quan mùi thơm của Yoshihashi et al. (2004) và dựa vào thang đánh giá mùi thơm của IRRI (1996). Sử dụng 3 giống làm đối chứng gạo IR50404 không thơm (cấp 0), gạo thơm thái có thơm (cấp 1) và Jasmine 85 có thơm (cấp 2). Qua kết quả, 50 dòng lúa IRRI đều không có mùi thơm (cấp 0). Bradbury et al. (2005) đã thiết kế 4 đoạn mồi ESP, EAP, INSP và IFAP, trong khi đó các cặp mồi ESP-EAP sẽ khuếch đại một đoạn DNA khoảng 580 bp cho cả 50 dòng lúa thơm và dòng lúa không thơm. Cặp mồi ESP-IFAP sẽ giúp nhận diện được gene thơm nếu sản phảm PCR có kích thước band 257 bp và cặp mồi INSP-EAP sẽ giúp nhận diện được gene không thơm khi sản phẩm $\mathrm{PCR}$ có kích thước band $355 \mathrm{bp}$. Nếu sản phẩm PCR có cùng lúc hai kích thước band $257 \mathrm{bp}$ và 355 bp thì dòng lúa đó sẽ mang kiểu gene thơm dị hợp. Trên lúa thơm tại vùng gene betain aldehyde dehydrogenease $2(\mathrm{BADH} 2)$ nằm trên nhiễm sắc thể số 8 có 8 cặp nucleotid ở exon thứ 7 bị loại bỏ, tuy nhiên ở lúa không thơm thì không bị mất đi vùng này.

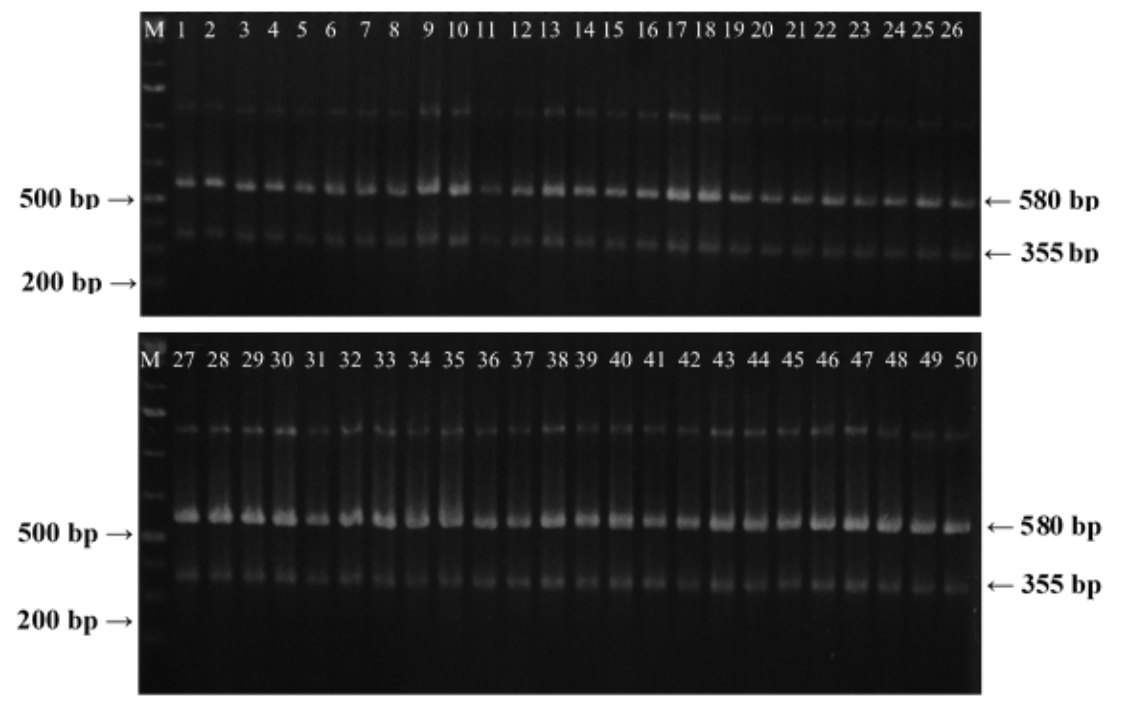

Hình 8. Phổ điện di sản phẩm PCR với mồi BADH2 trên gel agarose $2 \%$ nhận diện các giống có mang gene đột biến $O s B A D H 2$

(M: thang chuẩn 1 kb plus, 1-50: tương úng số thư tự các dòng lúa IRRI được trình bày trong Bảng 1) 
Qua kết quả phân tích sản phẩm PCR trên gel agarose $2 \%$ (Hình 8 ), 50 dòng lúa IRRI đều mang gene không thơm, không có dòng nào mang gene thơm, như vậy dấu phân tử này có mức độ phù hợp giữa kiểu gene và kiểu hình là $100 \%$.

Như vậy qua đánh giá kiểu gene chất lượng kết hợp phân tích với các chỉ số sinh hóa của hạt gạo, dòng IR 86385-172-1-1-B (số thứ tự 18) mang kiểu gene waxy thấp, có hình dạng hạt gạo thon dài. Vì vậy đây là dòng lúa tiềm năng cần được tiếp tục nghiên cứu và phát triển.

\section{KẾT LUẬN}

Tóm lại, qua việc ứng dụng 3 chỉ thị phân tử DRR-GL, Wx-inl và BADH2 đã giải thích được sự phù hợp giữa kiều gene và kiểu hình trên $82 \%$.

Đã tuyển chọn được dòng lúa IR 86385-172-11-B có mang đặc tính như hạt gạo thon dài (chiều dài hạt $7,12 \mathrm{~mm}$ ), hàm lượng amylose thấp $(17,51 \%)$, độ bền thề gel rất mềm $(86,67 \mathrm{~mm})$, nhiệt trở hồ trung bình (cấp 5).

\section{LỜI CẢM TẠ}

Nghiên cứu được tài trợ bởi dự án Nâng cấp Trường Đại học Cần Thơ VN14-P6 (vốn vay ODA từ Chính phủ Nhật Bản).

\section{TÀI LIỆU THAM KHẢO}

Bradbury, L. M., Henry, R. J., Jin, Q., Reinke, R. F., $\&$ Waters, D. L. (2005). A perfect marker for fragrance geneotyping in rice. Molecular Breeding, 16(4), 279-283.

Bùi Chí Bửu \& Nguyễn Thị Lang. (2000). Một số vấn đề cần biết về gạo xuất khẩu. NXB Nông nghiệp Thành phố Hồ Chí Minh.

Cagampang, C. B., Perez, C. M., \& Juliano, B. O. (1973). A gel consistency for eating quality of rice. Sci. Food. Agric, 24, 89-94.

Cai, H., Xu, D., Zhou, L., Cheng, J., Zhang, Z., Wu, J., \& You, A. (2015). Development of PCRbased CNP marker of rice Waxy gene with confronting two-pair primers. Russian Journal of Genetics 51, 673-676.

Cai, X. L., Wang, Z. Y., Xing, Y. Y., Zhang, J. L., \& Hong, M. M. (1998). Aberrant splicing of intron 1 leads to the heterogeneous $5^{\prime}$ UTR and decreased expression of waxy gene in rice cultivars of intermediate amylose content. The Plant Journal, 14, 459-465.

Calingacion, M., Laborte, A., Nelson, A., Resurreccion, A., Concepcion, J. C., Daygon, V. D., ... \& Fitzgerald, M. (2014). Diversity of global rice markets and the science required for consumer-targeted rice breeding. PloS one, 9(1), e85106.

Cruz, N. D., \& Khush, G. S. (2000). Rice grain quality evaluation procedures. In R.K. Singh, U. S. Singh, \& G. S. Khush (Eds.), Aromatic rices (pp.15-28).

Doyle, J. J., \& Doyle, J. L. (1990). Isolation of plant DNA from fresh tissue. Focus, 13-15.

Graham, R. (2002). A Proposal for IRRI to Establish a Grain Quality and Nutrition Research Center. IRRI Discussion Paper, No. 44. Los Banos (Philippines): International Rice Research Institute. $15 \mathrm{p}$.

Harlan, J. R., De Wet, J. M. J., \& Price, E. G. (1973). Comparative evolution of cereals. Evolution, 27(2), 311-325.

IRRI. (2013). Standard Evaluation System for Rice (SES). Rice Science for a Better World. $31 \mathrm{pp.}$

Jenning, P. R., \& Coffman, K. H. E. (1979). Rice improvement. IRRI.

Juliano, B. O. (1971a). Rice chemistry and technology. The American Association of cereal chemists, Ine Mumesita, USA.

Juliano, B. O. (1971b). A simplified assay for milled rice amylose. Cereal Sci. Today, 16, 334-360.

Juliano, B. O., \& Villareal, C. P. (1993). Grain quality evaluation of world rices. International Rice Research Institution.

Khoomtong. A., \& Noomhorm, A. (2015). Development of a Simple Portable Amylose Content Meter for Rapid Determination of Amylose Content in Milled Rice. Food Bioprocess Technology, 8(9), 1938-1946.

Little, R. R., Hilder, G. B., \& Dawson, E. H. (1958). Differential effect of dilute alkali on 25 varieties of milled white rice. Cereal Chem., 35:111-126.

McKenzie, K. S., \& Rutger, J. N. (1983). Genetic analysis of amylose content, alkali spreading score, and grain dimensions in rice. Crop Sci., 23, 306-313.

Nguyễn Ngọc Đệ. (2008). Giáo trình cây lúa. Nhà xuất bản Đại học Quốc gia Thành phố Hồ Chí Minh.

Nguyễn Thị Lang \& Bùi Chí Bửu. (2004). Xác định gene fgr điều khiển tính trạng mùi thơm bằng phương pháp Fine Mapping với microsatellites. Hội nghị quốc gia về chọn tạo giống lúa.

Nguyễn Thị Lang. (2005). Nghiên cứu biến động di truyền trên hàm lượng amylose của gạo (Oryza Sativa L.). Tạp chí Khoa học công nghệ Nông nghiẹp, 12, 24-20.

Ramkumar, G., Sivaranjani, A. K. P., Pandey, M. K., Sakthivel, K., Shobha Rani, N., Sudarshan, I., Prasad, G. S. V., Neeraja, C. N., Sundaram, R. M., Viraktamath, B. C., \& Madhav, M. S. (2010). Development of a PCR-based SNP 
marker system for effective selection of kernel length and kernel elongation in rice. Molecular Breeding, 26, 735-740.

Statgraphics, 1988. A statistical graphics software system. Disasters, 12, 304.

Yoshihashi, T., Nguyen, H. T. T., \& Kabaki, N. (2004). Area dependency of 2-acetyl-1-pyrroline content in an aromatic rice variety, Khao Dawk Mali 105. Japan Agricultural Research Quarterly, 38, 105-109.

Xie, L. Y., Lin, E. D., Zhao, H. L., \& Feng, Y. X. (2016). Changes in the activities of starch metabolism enzymes in rice grains in response to elevated $\mathrm{CO} 2$ concentration. International journal of biometeorology, 60(5), 727-736.

Zhang, C., Zhu, J., Chen, S., Fan, X., Li, Q., Lu, Y., Wang, M., Yu, H., Yi, C., Tang, S., Gu, M., \&
Liu, Q. (2019). Wxlv, the Ancestral Allele of Rice Waxy Gene. Molecular Plant, 12, 1157-1166.

Zhou, Z., Robards, K., Helliwell, S., \& Blanchard, C. (2017a). Effect of storage temperature on rice thermal properties. Food Research International, 43(3), 709-715.

Zhou, H., Li, P., Xie, W., Hussain, S., Li, Y., Xia, D., ... \& He, Y. (2017). Genome-wide association analyses reveal the genetic basis of stigma exsertion in rice. Molecular plant, 10(4), 634-644.

Zhou, H., Xia, D., \& He, Y. (2019). Rice grain quality - traditional traits for high quality rice and health-plus substances. Molecular Breeding, 40,1 . 